\title{
ICE-SHEET DYNAMICS OF WARTA GLACIATION (SAALE) IN THE MARGINAL ZONE OF KNYSZEWICZE AREA, NORTHEASTERN POLAND
}

\author{
Joanna Rychel ${ }^{1}$, Barbara Woronko ${ }^{2}$, Mirosław T. Karasiewicz ${ }^{3}$, Pawel Szymczuk ${ }^{4}$, Marcin Morawski ${ }^{1}$ \\ ${ }^{1}$ Polish Geological Institute - National Research Institute, Rakowiecka 4, 00-975 Warsaw, Poland; \\ joanna.rychel@pgi.gov.pl \\ ${ }^{2}$ Faculty of Geology University of Warsaw, Żwirki i Wigury 93, 02-089 Warsaw, Poland; \\ bworonko@uw.edu.pl \\ ${ }^{3}$ Faculty of Earth Sciences, Nicolaus Copernicus University, Lwowska 1, 87-100 Toruń, Poland; \\ mtkar@umk.pl \\ ${ }^{4}$ Faculty of Geography and Regional Studies, University of Warsaw, Krakowskie Przedmieście 30, \\ 00-927 Warsaw, Poland
}

\begin{abstract}
The paper presents a research on a marginal zone near Knyszewicze in the southern part of Sokółka Hills (northeastern Poland). Terminal moraine hills are arranged amphitheatrically in a lobal pattern. Dynamics of the Knyszewicze frontal ice-sheet lobe during the Saale Glaciation and successive stages of the marginal zone near the village of Knyszewicze were reconstructed based on sedimentary and geomorphological analysis, using a digital elevation model and morpholineaments. Three main phases of the Knyszewicze glacial-lobe activity were identified including accumulation of glaciofluvial deposits, advances of the ice margin and ice-lobe retreat. Moraine hills developed at a stable ice-lobe terminus, initially as short end-moraine fans with the following sequence of lithofacies $G h \Rightarrow S G h \Rightarrow S h$ or $G m \Rightarrow G h \Rightarrow S h$. Such a sequence indicates cyclic sheet-floods. During a small but dynamic advance of the ice sheet terminus, these deposits were moved forward and monoclinally folded, then furrowed with sloping faults due to horizontal pressure. Typical thrust-block push moraines developed in this way. Ice sheet advance took place when permafrost was present in the substratum and very high water pressure occurred at glacial terminus. Inside a lobal configuration of moraines, there is a rich inventory of glacial forms with a classic terminal depression in the central part. Based on this landform pattern, their shape, rhythm and glaciotectonic disturbances, the land relief may be referred to as a hill-hole pair. The structure of Horczaki Knoll, deposited on the sub-Quaternary tectonic structure, significantly contributed to a development of this marginal zone.
\end{abstract}

Key words: ice lobe, marginal zone, glaciotectonic disturbances, thrust-block push moraines, morpholineaments.

Manuscript received 22 July 2015, accepted 17 November 2015

\section{INTRODUCTION}

Glacial lobes represented a clear morphological element in a marginal part of the Pleistocene ice sheets in Europe, Asia and North America. Such situation is best known from the Vistulian Glaciation area in Poland (e.g. Galon and Roszko, 1961; Roszko, 1968; Kozarski, 1995; Karasiewicz, 2006; Kasprzak, 2007; Morawski, 2009b; Wysota and Molewski, 2011; Narloch et al., 2013) and other regions of Europe (e.g. Boulton et al., 2001; Houmark-Nielsen, 2004; Johansson et al., 2011), as well as North America (e.g. Punkari, 1997; Kovanen and Slaymaker, 2004; Mickelson and Colgan, 2004) and Asia (e.g. Grosswald, 1998). Glacial lobes were more dynamic compared to the main body of ice, whereas the frontal ice-sheet lobes could be the effect of glacial surges or ice streams as described by several authors (Echelmeyer and Harrison, 1990; Echelmeyer et al., 1991; Patterson, 1998; Marks, 2002, 2005; Holland et al., 2008; Wysota and Molewski, 2011).

Mechanisms that favour development and functioning of the Pleistocene glacial lobes on the European Plain were described in detail by Narloch et al. (2013). The authors point out to complex relationships between the ice sheet, its substrate, climate and water circulation within and beneath the ice sheet body, as well several other factors.

The course and functioning of the outlet lobes are often determined by substrate topography and rheological conditions of subglacial sediments. According to Piotrowski 


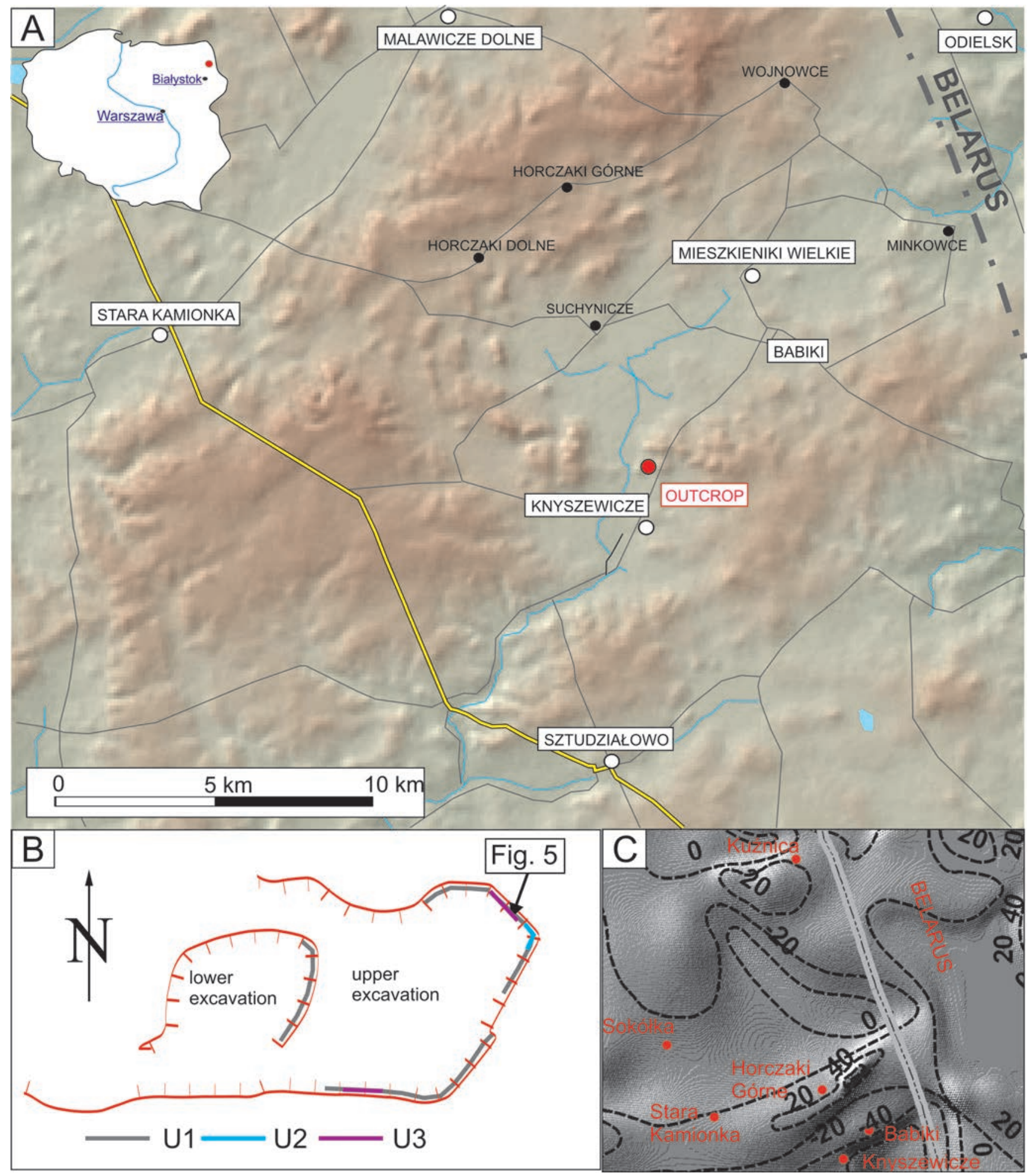

Fig. 1. Location sketch of Knyszewicze area. A - terrain model, B outcrop; C - relief of sub-Quaternary deposits.

(2006) and Boulton (2006), subglacial meltwaters were of major importance to the mechanism of ice movement and dynamics. Under favourable conditions, presence of water at the ice-substratum interface could result in development of a water film, which consequently may lead to décollement of an ice-sheet from its base (Piotrowski and Kraus, 1997; Arnold and Sharp, 2002; Woodward et al., 2003) and conse- quently, to basal sliding (Hermanowski and Piotrowski, 2009; Narloch et al., 2013). Basal sliding may cause an increased rate of ice sheet advance (Iverson et al., 1995). Scientific studies showing the influence of basal sliding on the ice-movement acceleration were conducted based on the analysis of glacial sediments and land relief in different marginal zones (Patterson, 1997; Piotrowski and Kraus, 1997; 
Piotrowski, 2006; Piotrowski and Tulaczyk, 1999; Stokes and Clark, 2001; Hermanowski and Piotrowski, 2009). Such studies were also conducted in contemporarily glaciated areas (e.g. Tulaczyk et al., 2000; Zwally et al., 2002).

In the 1970s, Mojski (1972) described a geomorphology of the Podlasie Lowland in eastern Poland, drawing attention to a lobal pattern of terminal moraines south of Sokółka. He presented an ice sheet gate near Knyszewicze as a peculiar landform in a marginal zone that could arise as a result of a glacial lobe or a small outlet glacier developed from the ice sheet of the Saale Glaciation (MIS 6).

The objective of the fieldwork carried out in the marginal zone of the Knyszewicze lobe was to reconstruct: (1) the accumulation conditions in the foreland of a glacial lobe, (2) the nature of glaciotectonic disturbances affecting the sediments, (3) the dynamics of the lobe terminus and (4) the nature of post-deposition disturbances and the conditions of their origin.

\section{GEOLOGICAL SETTING}

The study area is located in the North Podlasie Lowland, in the area of Sokółka Hills (Kondracki, 2000), at a distance of ca. $40-50 \mathrm{~km}$ to the northeast of Białystok. The relief of this area results from a glacial motion during the Saale Glaciation (Boratyn, 2003), which was sliding over the area of the Sokółka Hills from two directions - the advance from the north was connected with the Biebrza lobe and the advance from the northeast was correlated with the Niemen lobe (Ber et al., 2012). Small frontal ice sheet lobes developed in a marginal zone of both ice streams, including the lobe of Knyszewicze (Banaszuk, 2010).

The direction of ice lobe advances during the Saale Glaciation (MIS 6) was reconstructed based on the geology and geomorphology and analysis of glacial morpholineaments. The described zone consists of several distinct moraine ridges, the structure of which was thoroughly investigated in the exposure at Knyszewicze. The site Knyszewicze is located in the arch-shaped zone of terminal moraines open to the northeast. It forms a lobe-like pattern that stretches from the environs of Wojnowiec in the northeast, through the village Horczaki Dolne to Knyszewicze in the southwest, and then it turns towards the village of Mienkowce in the southeast (Fig. 1). The lobe stretches over ca. $9 \mathrm{~km}$ in the SW direction from the state border and has a width ranging from ca. $4 \mathrm{~km}$ in the most western part to $7.5 \mathrm{~km}$ in the east. The length of the moraine sequence is ca. $17.5 \mathrm{~km}$. It consists of 27 distinct forms, mostly terminal accumulation moraines and push moraines, particularly in the southern part of the lobe (Boratyn, 2006), but also dead-ice moraines. These forms are arranged in two and in the north-western part of the ridge, even three sequences parallel to each other (Fig. 1). The highest point of these moraines is located northwest of the Wojnowiec village ( $240 \mathrm{~m}$ a.s.1.) and the lowest one near Knyszewicze (ca. $180 \mathrm{~m}$ a.s.1.). Their morphometry is varied, the width at the base of the smallest terminal moraine is ca. 200-300 $\mathrm{m}$ and the width of the largest one ranges from 200 to $800 \mathrm{~m}$, with a length of ca. $3.5 \mathrm{~km}$. Most of the terminal moraines have asymmetrical slopes; proximal slopes are steeper than the distal ones - from 2 to 15-20 (Fig. 2). Mo- raines near Knyszewicze and Horczaki Dolne have the steepest slopes.

In the north, the moraines are enclosed by a long ridge referred to as Horczaki Knoll, rising above the surrounding land in the NE-SW direction, i.e. parallel to the moraines marking the northern and the southern range of the Knyszewicze lobe (Fig. 2). The Horczaki Knoll had a very significant impact on the palaeogeography of this area and advances of the ice sheets, the tectonic settings of which are connected with the activity of the Quaternary substratum (Fig. 3). Probably already during the Elster Glaciation, and certainly during the transgression of the Saale ice sheet, the Horczaki Knoll represented a considerable barrier in the terrain, causing the accumulation of ice sheet masses and sediments or diversion of the advancing ice sheet (Boratyn, 2006).

Outwash plains are located southeast of the moraines, while dead ice moraines and less frequently kames occur in the hinterland of the moraines. A large terminal depression filled with silt deposit is located near the village of Suchynicze (Fig. 2).

In the southwesternmost part of the moraine, near the Knyszewicze village, a relatively large gate (up to $20 \mathrm{~m}$ wide) with steep slopes cuts the moraines. According to Mojski (1972), it is a classical example of a glacial gate (Figs 1,2). A two-level excavation located in the hill adjacent to the glacial gate provided access to the internal structure of the moraine (Fig. 1). The excavation rose ca. $25 \mathrm{~m}$ above the surface of the surrounding terrain. The width of the hill is ca. $200 \mathrm{~m}$, and the absolute height before the exploitation was over $192.5 \mathrm{~m}$ a.s.1., while inclination of slopes in the southwestern part was up to 10-15.

\section{MATERIAL AND METHODS}

The land relief near Knyszewicze and sediments exposed in this area were analysed in detail to reconstruct the spatial and temporal dynamics of the ice sheet in the area of Sokółka Hills and Białystok Plateau.

\section{Analysis of the land relief}

The analysis of the land relief in the environs of Knyszewicze consisted in the determination of glacial morpholineaments over an area of $1447 \mathrm{~km}^{2}$. This has become an increasingly versatile tool for integrated palaeogeomorphological and palaeogeographical reconstruction (cf. Morawski, 2005). The first stage of the study consisted in identification of linear elements of the postglacial relief according to the classification of Rychel and Morawski (2014): moraines (Mo), crevasses (Crev), terminal depressions (Depr), valleys (Val), closed depressions with no outflow (Pit), outwash fans (Fan) and hills on the outwash plains, uplands and dead ice moraines $(\mathrm{Hu})$. The analysis was performed by the GIS software, using a shaded and coloured Digital Terrain Elevation Data (DTED 2), an exaggerated digital elevation model (resolution of $30 \mathrm{~m}$ ), topographic maps (WMS) and geological maps, in particular the Sokółka sheet of the Detailed Geological Map of Poland in scale 1:50,000. The length of lineaments was counted within the groups of genetically and 

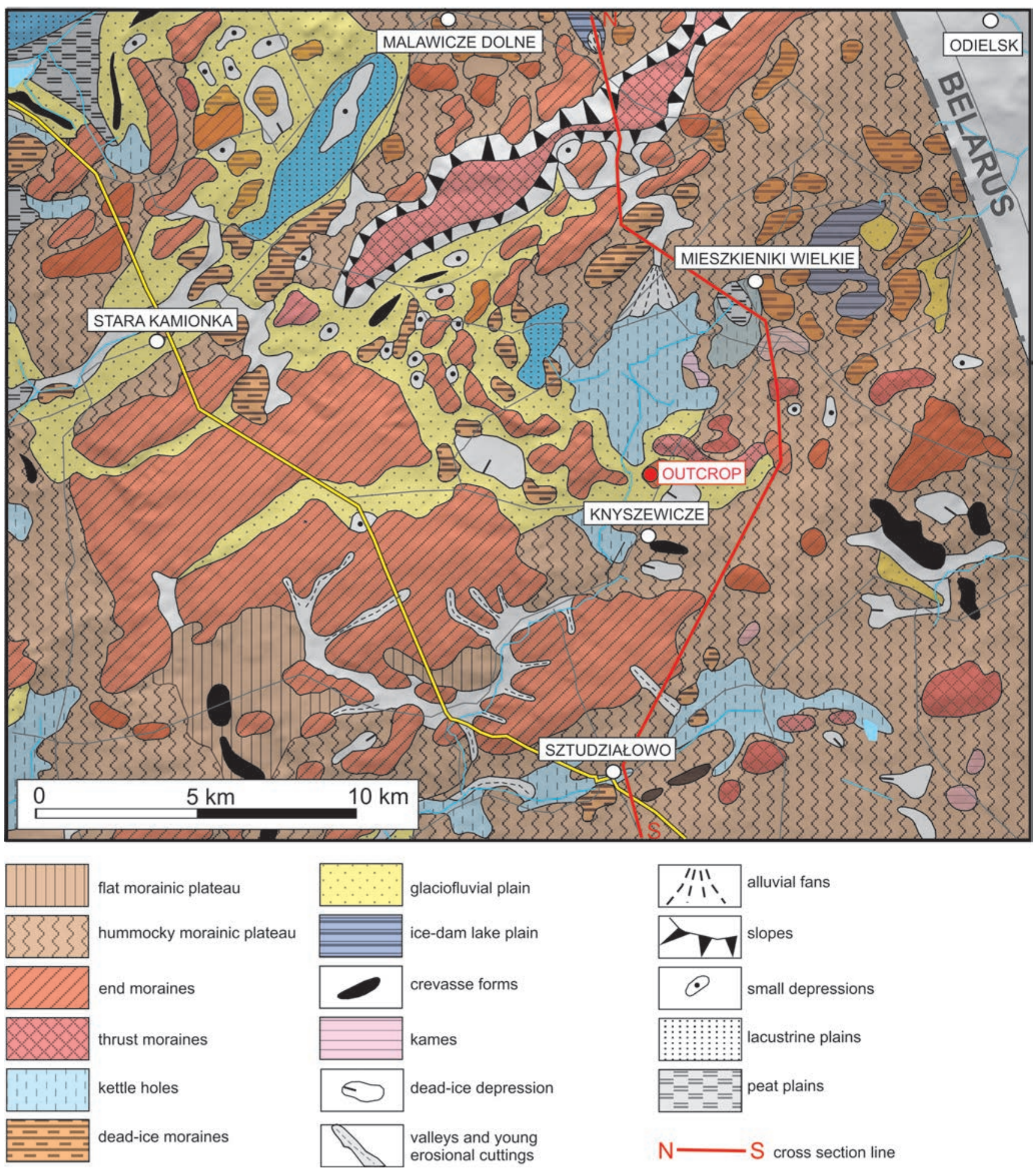

Fig. 2. Geomorphological sketch of the marginal zone of the Knyszewicze lobe (Boratyn 2003, Laskowski 2000, modified).

chronologically interrelated landforms, at intervals of every $5^{\circ}$. Results are presented in rosette diagrams (Fig. 4).

The second stage of the analysis consisted of identification of regions where genetically identical groups of glacial lineaments had similar orientation, i.e. indicated different dynamics of ice sheet body, including a direction of the ice sheet advance. This in turn could be used to determine a range of potential ice lobes (cf. Morawski, 2003, 2009a, b).

\section{Structural analysis of sediments}

A detailed lithofacial analysis of sediments was conducted, following the code of Pisarska-Jamroży and Zieliński (2012). Measurements of structures in the stratified sediments and registered faults were made. In addition, the maximum particle size (MPS) was measured in gravels. Measurements of 10 clasts were made directly from the out- 


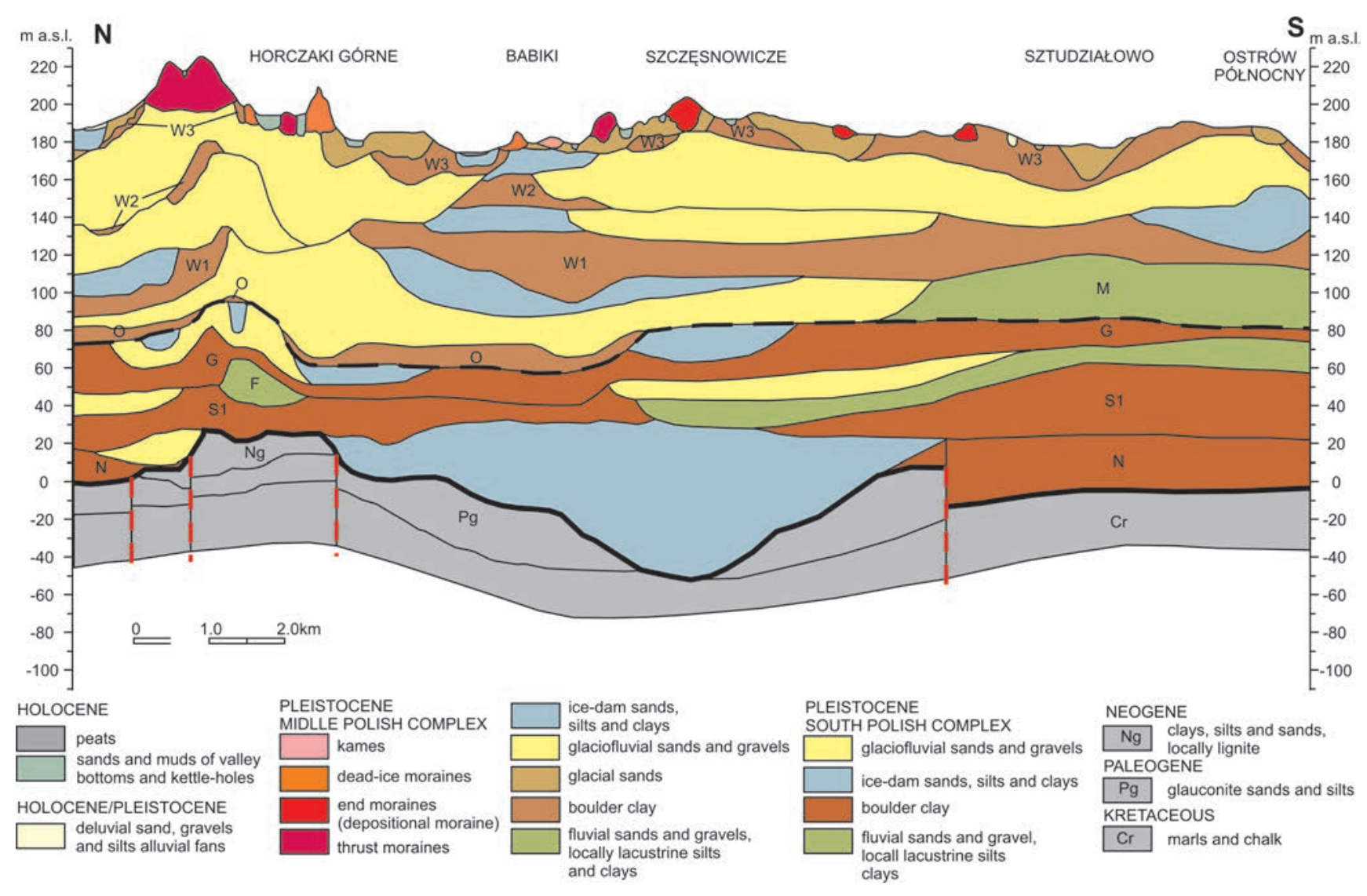

Fig. 3. Schematic geological cross-section.

crop wall and in the case of deposits filling a subglacial channel from a scree located at the base of the channel.

\section{RESULTS}

\section{Palaeogeographical domains}

Groups of postglacial elongated forms (e.g. terminal moraines and eskers) were distinguished on the basis of glacial morpholineaments near the Knyszewicze village, and consequently the direction of ice-sheet transgression was determined (Fig. 4). Two domains, including the Horczaki Knoll and Knyszewicze lobe moraines were distinguished, different from each other in the orientation of the same groups of glacial lineaments, i.e. indicating direction of the ice sheet movement. The azimuth of the axis of the strongest thrust of the continental ice sheet was equal to $171^{\circ}$, obtained for the domain of the Horczaki Knoll, recurred throughout the analysed area and probably corresponded to the main direction of the ice sheet advance during the maximum range of the Saale Glaciation (MIS 6) from the north-northwest. On the other hand, the azimuth of the thrust within the domain of the Knyszewicze lobe moraine was $23^{\circ}$ and was consistent with measurements of the overthrust faults at the eastern wall of the outcrop. This indicated a movement of the lobe from the north-northeast (Fig. 4).

\section{Sediments - description and interpretation}

A series of sand and gravel deposits with a total thickness of ca. $10 \mathrm{~m}$ is exposed at two levels of the excavation pit at
Knyszewicze. The distinguished lithofacies were grouped into three units (U1-U3), contacting laterally with one another.

\section{Unit 1 (U1)}

It consists of horizontally-stratified gravel $(G h)$, massive gravel $(G m)$, horizontally stratified sand with gravel $(S G h)$ and sand $(S h)$. These sediments form gravel and sand sequences: $G h \Rightarrow S G h \Rightarrow S h$ and $G m \Rightarrow G h \Rightarrow S h$. The strata are characterised by a large strike and tiled shape (Figs 5 and 6). Massive gravel beds $(\mathrm{Gm})$ are 5-20 $\mathrm{cm}$ thick, whereas sand-with-gravel beds ( $S G m$ ) from 15 to $25 \mathrm{~cm}$. The depth of washouts of occasionally recorded trough cross-stratified sandy and gravelly sediments $(S G t)$ does not exceed $40 \mathrm{~cm}$. Measurements of maximum particle size (MPS) of the ten largest clasts from horizontally stratified gravel lithofacies $(G h)$ and massive gravel $(G m)$ were $52-81 \mathrm{~mm}$. The MPS value increased towards the surface, both in the eastern and northern part of the outcrop. The longer axes of clasts were perpendicular to the water flow direction.

\section{Unit 2 (U2)}

Horizontally stratified fine-grained sand and fine-grained gravel $(S h, G h)$, and sands with ripple-cross lamination $\mathrm{Sr}$ ) were recorded in the eastern wall of the outcrop with $\mathrm{N}-\mathrm{S}$ orientation. The sediments were observed in a narrow zone (up to $3 \mathrm{~m}$ ) with a thickness of up to ca. $3.5 \mathrm{~m}$. Sediments of the unit 2 are in a direct contact with the stratified gravel-sand sediments (unit 1) from the south, and with sediments filling the channel (unit 3) from the north. 


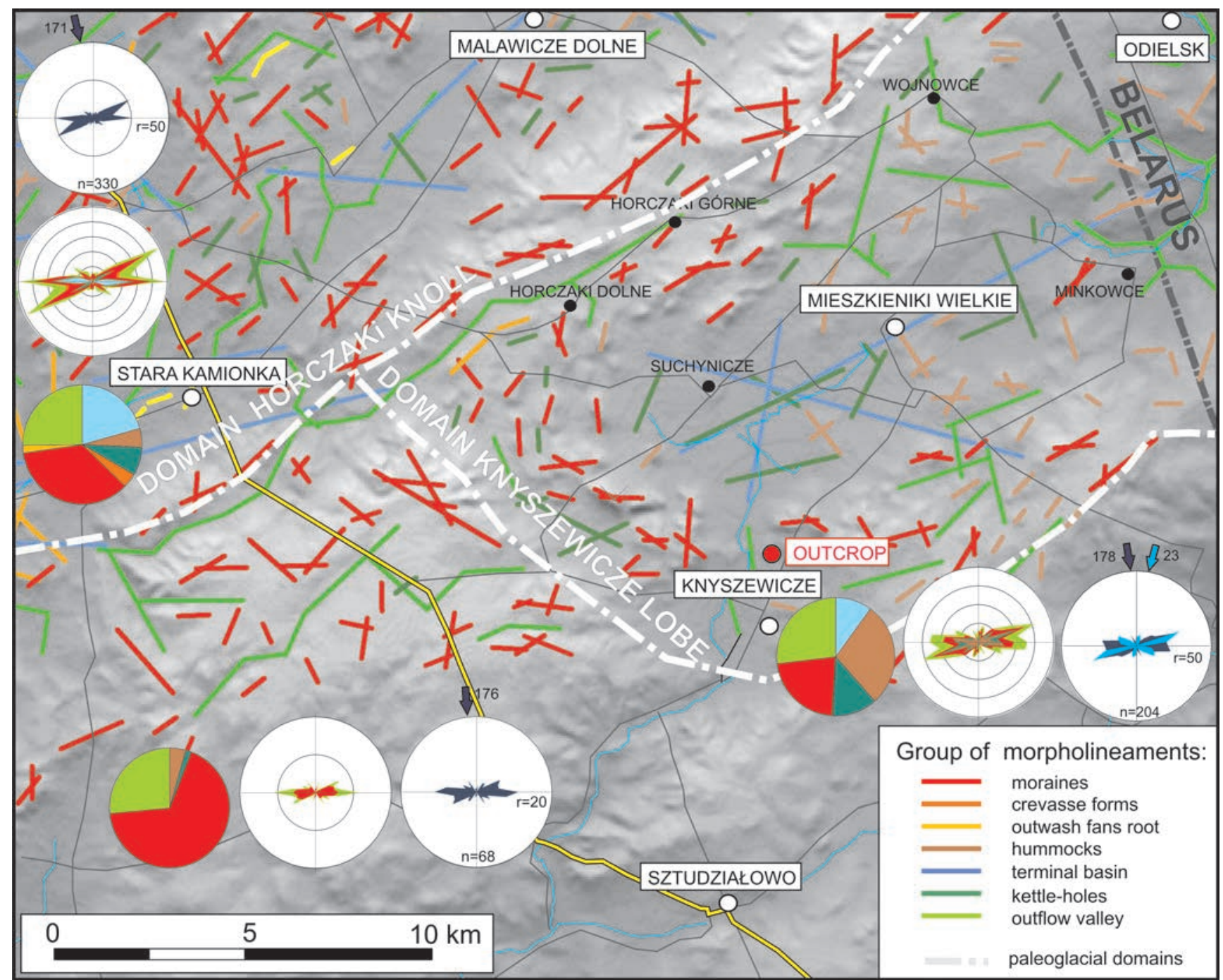

Fig. 4. Distribution of glacial morpholineaments within the Knyszewicze marginal zone Black arrow - main overthrust direction during the last glaciation in the study area, blue arrow - direction of ice flow in the Knyszewicze lobe, $n$ - number of measurements, $r$ - radius of length.

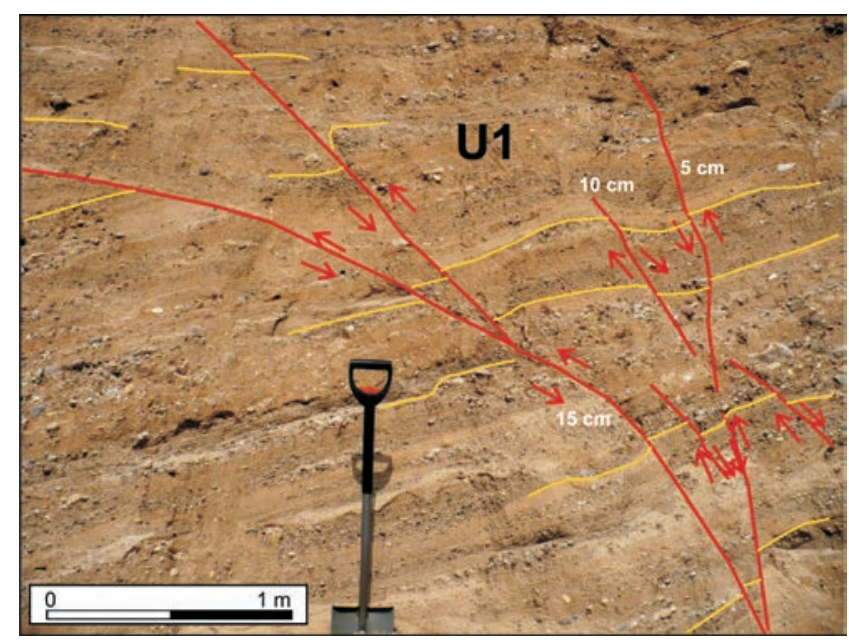

Fig. 5. Glaciotectonically disturbed sediments of the end-moraine fan at Knyszewicze site. U1 - unit 1 - description in text.

\section{Unit 3 (U3)}

In the northern and southern wall of the upper part of the outcrop, horizontally stratified sand-with-sand beds are cut by channels. The channel observed on the northern wall is ca. $5 \mathrm{~m}$ deep and $7 \mathrm{~m}$ wide in a lower part and ca. $15 \mathrm{~m}$ wide in the upper part. The channel on the southern wall is ca. $4 \mathrm{~m}$ deep and $11 \mathrm{~m}$ wide. In both cases, the channel's slopes are very steep, inclined at $60-90^{\circ}$ (Fig. 7). The bottom of the channel visible on the northern wall is located lower than the channel on the southern wall and the washout surface is inclined northwards, i.e. towards the inner parts of the Knyszewicze lobe. The bottom part of the northern channel was filled with massive gravel (Gm; ca. $1 \mathrm{~m}$ thick) with angular sandy clasts of stratified fine-grained sand deposits with a diameter of up to $20 \mathrm{~cm}$ and boulders with a diameter of up to $40 \mathrm{~cm}$. This deposit is overlain by massive matrix-supported gravels $(G m)$ and tabular cross-stratified gravels $(G p)$ with poorlymarked stratification. In the uppermost layer, a rhythmite of massive silty diamicton $(\mathrm{Dm})$ and poorly sorted, horizontally and high angle cross-stratified gravels ( $G h, G p)$ was re- 

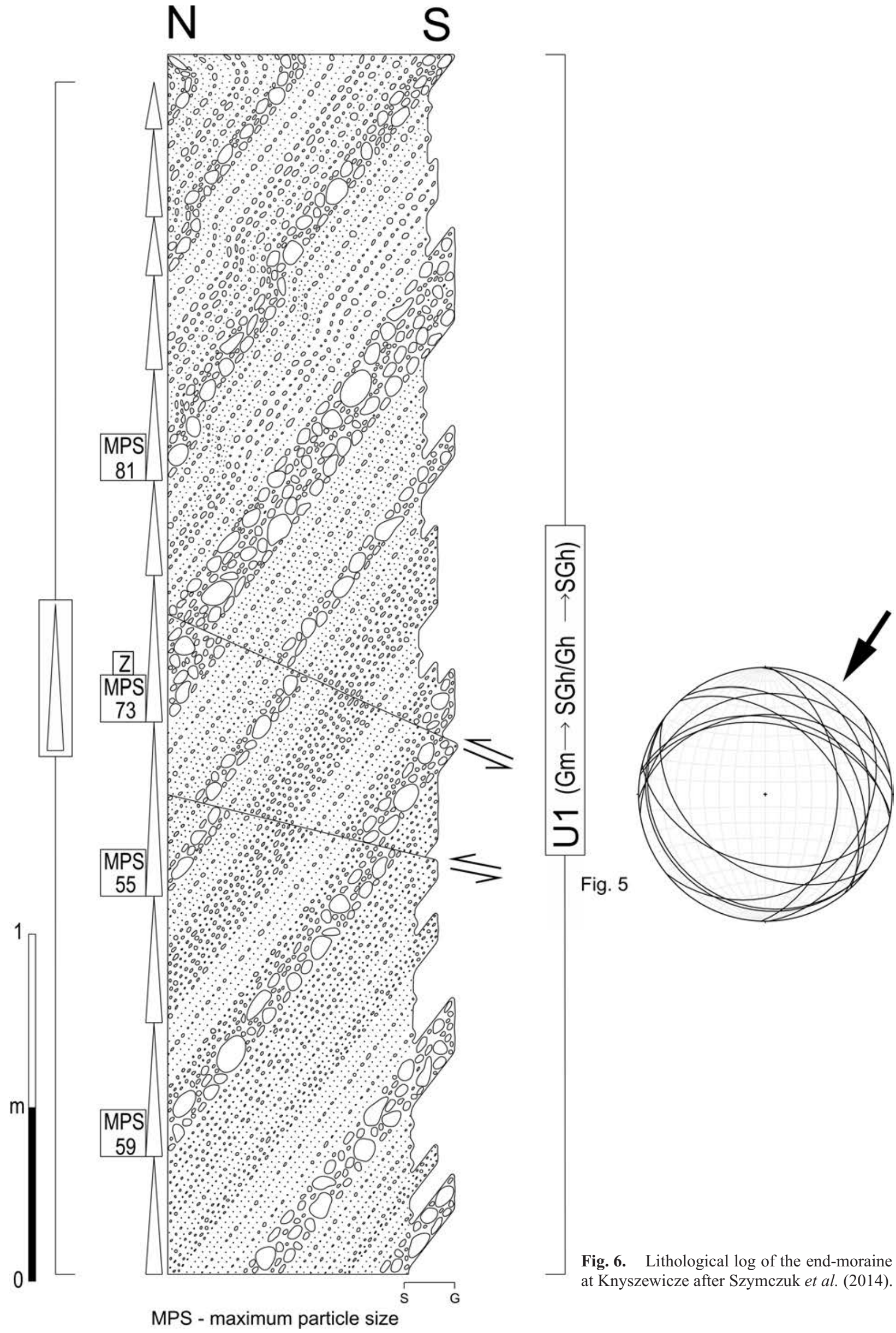

Fig. 6. Lithological log of the end-moraine fan at Knyszewicze after Szymczuk et al. (2014). 


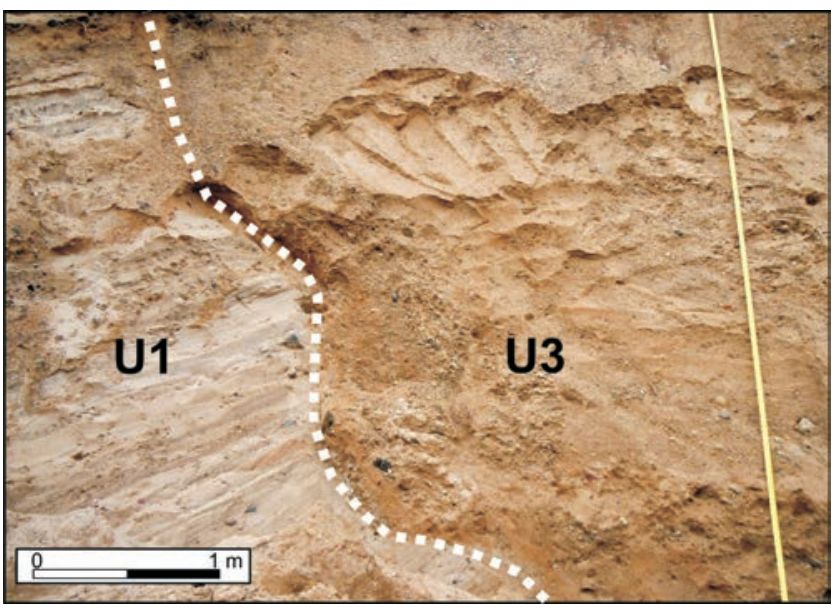

Fig. 7. Contact zone of sediments filling a deep channel (U3) and disturbed sediments of the end-moraine fan (U1) after Szymczuk et al. (2014).

corded, with a bed thickness of $1.5 \mathrm{~m}$, which turned into well-sorted, horizontally cross-stratified gravel deposits towards the centre of a washout (high angle $-G p$ ). MPS for the recorded gravel deposits in the floor of the channel's infilling was $180 \mathrm{~mm}$.

On the southern wall, massive gravel $(\mathrm{Gm})$ with a thickness of ca. $0.7 \mathrm{~m}$ was found below the channel, which cuts across the gravel-sand sediments at a right angle in relation to sediment stratification.

\section{Sediment disturbances - description and interpretation}

All rhythmically stratified gravelly and sandy sediments observed in the outcrop were strongly disturbed and monoclinally positioned at an angle of $40-55^{\circ}$ northwards. Two types of faults were noted: normal, steep and reverse faults. The normal faults were steep and their fault planes dip $46-83^{\circ}$ northwards. They were observed mainly in the northern part of the wall (Figs 5,6). The reverse faults with their planes dipping $11-44^{\circ}$ north-northeastwards indicated a north-northeastern direction of the ice-sheet thrust. They were observed in the eastern wall of the upper outcrop only, mainly in sediments of the unit 2. Deposits filling the channel (U3) were involved in discontinuous deformations (Fig. 7). A total thickness of the disturbed sediments in the outcrop was equal at least $30 \mathrm{~m}$.

On the northern wall of the outcrop, a sediment flexure occurred in the surface zone (up to $0.7 \mathrm{~m}$ ), which was a result of mass movements. It represented the so-called downslope bending of strata. They developed at the time when persistent, long-term permafrost retreated and sediments were plastic. This is supported by a steep inclination of the slopes of this landform.

\section{PHASES OF GLACIAL-LOBE ACTIVITY}

Based on the conducted study, three phases of the Knyszewicze glacial lobe activity were distinguished: phase I with deposition of glaciofluvial deposits in the ice sheet front, phase II with advances of the ice margin and phase III with the ice lobe retreat. The phases reflect a dynamics of the ice front in the marginal zone near Knyszewicze.

\section{Phase I: accumulation of glaciofluvial deposits}

The first phase of the marginal zone of the Knyszewicze lobe starts from the accumulation of glaciofluvial sediments (U1 and U2) building the terminal moraine (Fig. 8). The presence of lithofacies sequences $G h \Rightarrow S G h \Rightarrow S h$ and $G m \Rightarrow G h$ $\Rightarrow S h$ indicates that their deposition occurred during nonchannelized, extensive and shallow sheet-flows. This flow was characterised by short-term surges, reflecting an ablational rhythm of the ice-sheet (Zieliński, 1993; Krzyszkowski and Zieliński 2002; Zieliński, 2015). During the flow maximum, strong aggradation prevailed and massive $(\mathrm{Gm})$ and horizontally stratified gravels $(G h)$ occurred. Horizontally stratified sand-with-gravel and sand ( $S G h$ or $S h)$ developed during lower flow stages. According to Krzyszkowski and Zieliński (2002), this type of sediment development indicated location of sediments in a distal zone of the end moraine fan (ice-marginal fan) of the type B2b. Sediments were deposited in the ice-contact zone, on steep fan slopes (Blair and McPherson, 1994; Krzyszkowski and Zieliński, 2002; Zieliński, 2015). The same type of deposition was observed in a southern part of the Knyszewicze lobe, at Babiki located ca. $2.5 \mathrm{~km} \mathrm{NE}$ from Knyszewicze (Figs 1,2). Thus, it appears that this type of sedimentation was common in a foreland of the Knyszewicze lobe. The end moraine fans were small and overlapping. A similar type of deposition was recorded in various parts of the Polish Lowlands (Kasprzak and Kozarski, 1984; Krzyszkowski et al., 1999; Krzyszkowski and Zieliński, 2002). The end moraine fan accumulation took place when the ice front was stabilized or slowly oscillating (Krzyszkowski and Zieliński, 2002). In the case of the end moraine fan of Knyszewicze, a thickness of sediments slightly increased towards the uppermost layer (the roof), which indicated that deposition took place during very slow advance of the ice front.

This ice sheet advance was followed by a retreat of the Knyszewicze lobe front. Sediments of the push moraine lost their support, which led to development of many normal faults. Based on the collected data, it is not possible to determine. how far the ice sheet front retreated.

\section{Phase II: advances of the ice margin}

Three parallel sequences of hills can be identified in the landscape of the northern and western part of the Knyszewicze lobe. They reflect subsequent advances or retreats of the Knyszewicze lobe, interrupted by episodes of ice front stabilization. On the other hand, a $15 \mathrm{~m}$ high single crest parallel to the ice margin occurs in the vicinity of Knyszewicze (Fig. 1A). The advance was followed by deformations in the end moraine fan, particularly in the eastern and central part of the outcrop (Figs 2, 8). Deformations occurred as thrustings of semi-coherent blocks along discrete fault planes. This stage of deformation was connected with a system of sloping faults, with a fault plane inclined at $11-44^{\circ}$ northwards. They were particularly well visible on the eastern wall of the out- 
crop (Figs 5, 6). Inclination of the fault planes indicates a north-northeastward direction of the ice sheet thrust that was responsible for deposition. Nevertheless, the advancing ice sheet did not pass through the analysed form and the folded structures did not develop either. The disturbed sediments were cut through by a deep channel, the bounding surface of which was dipping at low angle towards the north (upstream dipping beds). This proved high energy of the water flow, concentration (channel on the northern wall) and low dispersion of waters (channel on the southern wall).

The analysed form is a result of the forward advance of the ice margin into the end moraine fan, which caused lateral compression of the moraine fan. The glacial stress field was generated by push-from-the-rear (Bennett, 2001). This type of deformation was characteristic for the thrust-block push moraines (Bennett, 2001) or thrust-dominated moraines (Boulton et al., 1999). Boulton et al. (1999) identified four ridge types in respect of compressive stress generated during deformation. The form at Knyszewicze represents large $(>5 \mathrm{~m}$ high) push moraines, with a single crest orientated parallel to the ice margin. According to Boulton (1986) and Boulton et al. (1999), a development of the outwash fan is a pre-requisite for push moraine formation. Steeply inclined moraine slopes at Knyszewicze may indicate a sudden advance of the ice sheet or even glacier surges (surge-type overthrusts). However, this approach is challenged by Boulton et al. (1999). Given the shape of the moraine hills, especially a steepness of the slopes and, in some cases, their clear asymmetry, most moraines can be assumed to have been composed of glaciotectonically disturbed sediments. Clarification of this issue is additionally hindered by a lack of outcrops in the moraines. The authors of the Detailed Geological Map of Poland did not provide sufficient answers either (Boratyn, 2006).

Numerous observations of the thrust-dominated push moraines around the margins of the Laurentide and European ice sheets indicated importance of permafrost in proglacial thrusting (e.g. Clayton and Moran, 1974; Astakhov et al., 1996). According to Boulton et al. (1999), permafrost is necessary for deformation development, although not everyone shares this view (e.g. Aber, 1988). Most probably, the permafrost was also present in the substratum during the advance of the Knyszewicze lobe. The prevalence of such conditions may be evidenced by presence of angular sandy clasts of stratified sand deposits in the bottom sediments filling a channel (Unit 3). This fact is also evidenced by the preserved primary structure of sandy clasts; a frozen sediment only can preserve an internal structure of loose sediments included in the fluvial transport (Mycielska-Dowgiałło, 1998; PisarskaJamroży and Zieliński, 2012; Weckwerth, 2010, Weckwerth and Pisarska-Jamroży, 2014). Most likely, presence of permafrost in the substratum led to a high pressure of water in the ice sheet terminus, which consequently broke through and carved a deep channel, the erosion of which resulted from the intensive drainage under the ice sheet. In such conditions, the N-type channel was formed (Nye, 1973, 1976) in sediments of the end moraine fan. Furthermore, the slopes of the channel are vertical, which could be a further proof that sediments of the end moraine fan were frozen at the time of erosion. One can arrive at similar conclusions based on the
NE

\section{A. STABILIZATION OF ICE-FRONT}

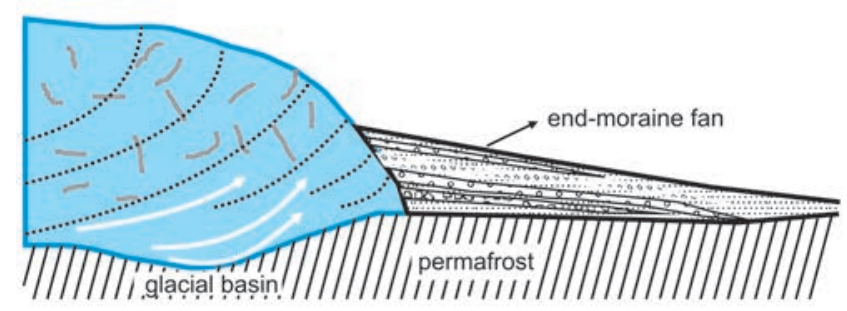

B. RETREAT OF ICE LOBE

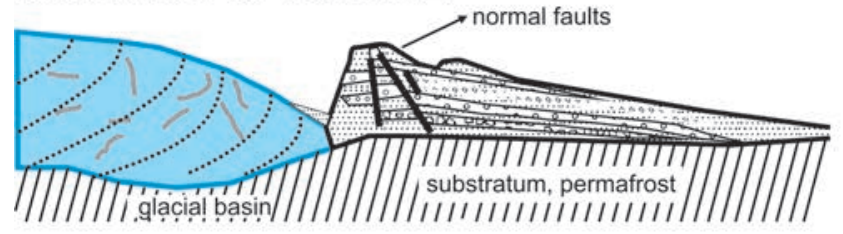

\section{ADVANCE OF AN ICE MARGIN}

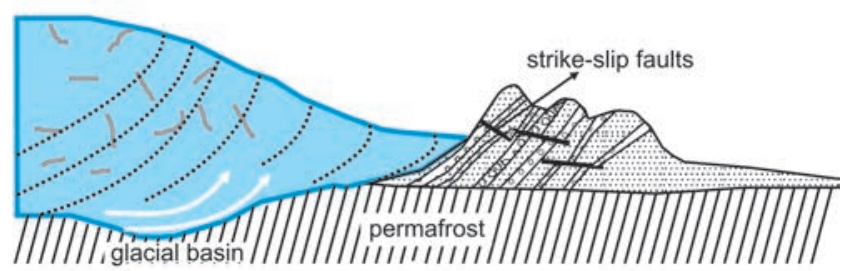

\section{RETREAT OF ICE LOBE}

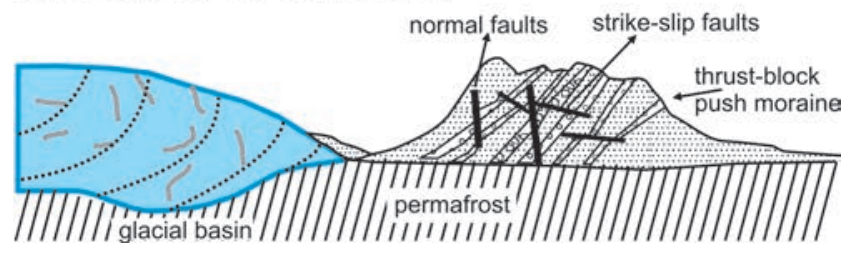

Fig. 8. Genetic model for sediment succession and landform formation at Knyszewicze. A - stabilized ice front and sedimentation of the end moraine fan; $\mathrm{B}$ - retreat of the ice lobe, $\mathrm{C}$-advance of the ice margin, $\mathrm{D}$ - retreat of the ice lobe

network of faults intersecting the sediments, which also suggests that the material exposed to disturbances was frozen at that time. A similar situation was described by Gałąka et al. (2009) from the site at Rożental in north-central Poland and Piotrowski $(1994,1997)$ from Germany.

A large depression filled with fine-grained sediments is located in the hinterland of the terminal moraine sequence of the Knyszewicze lobe (Fig. 2; Boratyn, 2006). According to van der Wateren $(1995,2005)$ and Beerten (2014), a push moraine always seems to be associated with a terminal basin. The existence of glacial basins can be explained by glaciotectonic processes, i.e. removal of attached frozen sediment/ bedrock from the underneath of the ice sheet.

At the second stage, small oscillations of the Knyszewicze lobe front could occur. This hypothesis may be con- 
firmed by the fact that sediments filling the eroded channel in the northern wall of the outcrop in the disturbed sediments (Unit 2) of the end moraine fan are involved in the deformations (Figs 7, 8). Sediments filling the channel were most likely frozen during the deformation. This fact is supported by brittle deformations which affected sediments of the unit 2 . Phase II was probably the last stage of the outermost marginal zone formation by the ice-sheet in the Knyszewicze lobe.

\section{Phase III - ice-lobe retreat}

The ice-sheet front retreated and consequently, the previously disturbed sediments lost their support. Most likely, the second generation of steep normal faults is connected with this stage of the marginal zone development. The prolonged stagnation of the ice sheet front resulted in a development of the terminal depression in the hinterland of terminal moraines. Slope processes occurred at the end of the final stage.

\section{DISCUSSION}

The end-moraine zone near Knyszewicze is an example of glaciotectonic disturbances recorded in the relief as a hill-hole pair when a sequence of hills of similar size and shape occurs along a relatively small distance of a terminal depression (Bluemle and Clayton, 1984; Boulton, 1986; Benn and Evans, 2010). This type of situation was described by Kasprzak (2007) from the Wielkopolska region near Sława where an ice lobe developed from the Vistulian ice sheet with the ice-contact fans at the terminus, subsequently folded as a result of the ice sheet front oscillation. Oscillatory movements were induced by winter changes in the ice balance. The advance was followed by the ice sheet stagnation and development of recessional moraine sequences.

Probably, the Knyszewicze lobe was most active and caused large disturbances in the sediments accumulated in the ice-contact zone near Knyszewicze as well as in other parts of the southern moraine sequence. This hypothesis may be supported by the fact that three arcs of moraines are present in the relief of the northern and western part of the lobe; they are not observed in the south, i.e. near Knyszewicze and Babiki (Fig. 1). The thus developed relief may indicate that the Horczaki Knoll could be a tectonically active and slowly lifted form (Boratyn, 2005). Therefore, the northern wing of the lobe was "sliding down" from the Horczaki Knoll, while the southern part was compressed.

The analysis of morpholineaments clearly shows that a subsequent advance associated with a development of the Knyszewicze lobe followed from NNE or NE (Fig. 8). The Horczaki Knoll (a large ridge with NNE-SSW course) played a relatively important role in its course and direction (Fig. 1). The knoll is probably a huge sub-Quaternary elevation with tectonic settings (Figs 1, 2, 4). During ice sheet overthrusts, the knoll was an unstable (labile) zone and the load of the advancing ice sheet resulted in indentation. The unstable structure could affect fragmentation of the ice body and development of ice sheet lobes. Presence of three moraine arcs in the northern part of the lobe could be caused by isostatic movements of the Horczaki Knoll and thus the "slip- page" of the lobe in the southern direction. After reaching the maximum range, the ice "push sideways", most likely mainly towards south or southwest, that is in agreement with sediment deformations at the site at Knyszewicze.

The flexure of glaciotectonically disturbed sediments of the end moraine fan at the site Knyszewicze, on the eastern wall in the surface layer (at a depth of ca. $0.7 \mathrm{~m}$ from the surface) follows a slope inclination, i.e. ca. $10^{\circ}$ (Fig. 5). The structure of sediments represents an example of bent rock layers developing in presence of permafrost. The flexure of strata is an effect of mass movements, in this case - solifluction, which most likely took place during the Vistulian Glaciation. It appears that mass movements covered the entire active layer of the long-term permafrost, i.e. a thickness of about $0.7 \mathrm{~m}$. This process occurred during one-sided freezing when solifluction consisted of two processes: (1) frost creep that repeated diurnal frost throughout a year and (2) gelifluction during a spring (Jahn 1970; French, 2007). The solifluction lobes being an effect of mass movements during the Vistula Glaciation, were recorded at the site of Jałówka in northeastern Poland (Woronko et al., 2013; Rychel et al., 2014).

\section{CONCLUSIONS}

The deposits of the marginal zone in the Knyszewicze recorded the dynamics of the small frontal ice-sheet lobe, which was isolated from the compact ice sheet of the Saale Glaciation (MIS 6) at the time of its retreat. The labile structure of the Quaternary substratum, which is manifested by the Horczaki Knoll, had probably a major impact on formation of the frontal ice sheet lobe in the vicinity of Knyszewicze and, at the same time, a direction of its advance. The marginal zone at Knyszewicze was formed during three phases:

1. The first one was associated with the development of the end-moraine fan, a deposition of which occurred within a contact zone of the ice sheet terminus. At that time, the ice sheet front was stationary, with only minor oscillations.

2 . The next stage was connected with a dynamic advance of the ice sheet front and disturbance in the end-moraine fan deposits. Disturbances resulted in development of thrustblock push moraines. The advance of the lobe took place at presence of permafrost in the substratum of its terminus and foreland. The permafrost was responsible for a very high water pressure in a subglacial zone and erosion of a deep channel which cuts the disturbed moraine deposits.

3. The last phase is associated with a withdrawal of the lobe front and development of a network of normal faults.

Such a scenario of events resulted in development of a heterogeneous marginal zone of hill-hole pair type, with well-developed terminal moraines and large, well-developed terminal depression in the hinterland.

The collected data did not answer a question on a type of the terminal lobe. Was it a result of surge advance the ice sheet, connected e.g. with a sudden hydrological change in the ice body? Or was it an ice-stream terminus connected with isostatic effect of the tectonic structure near the Horczaki Knoll. At this stage of the research, it is impossible to answer these questions. 


\section{Acknowledgements}

The research was funded by the grant of the National Science Centre no. UMO-2013/09/B/ST10/02118.

\section{REFERENCES}

Aber, J.S., 1988. Ice-shoved hills of Saskatchewan compared with Mississippi delta mudlumps - implications for glaciotectonic models. In: Croot, D.G. (Ed.), Glaciotectonics Forms and Processes. Balkema, Rotterdam, 1-9.

Arnold, N., Sharp, M., 2002. Flow variability in the Scandinavian ice sheet: modeling the coupling between ice sheet flow and hydrology. Quaternary Science Reviews 21, 485-502.

Astakhov, V.I., Kaplyanskaya, F.A., Tarnogradiskiy, V.D., 1996. Pleistocene permafrost of West Siberia as a deformable glacier bed. Permafrost and Periglacial Processes 7, 165-191.

Banaszuk H., 2010. O wieku i genezie rzeźby polodowcowej Niziny Północnopodlaskiej na podstawie analizy geomorfologicznej i dat TL. In Banaszuk H., Banaszuk P. (Eds.) Zagadnienia morfogenezy Niziny Północnopodlaskiej. Rozprawy Naukowe Oficyna Wydawnicza Politechniki Białostockiej 198, 7-130.

Beerten, K., 2014. An overview of deformation and erosion phenomena related to advancing ice sheets in lowland Europe. Externa Report SCK•CEN-ER-254, 14/Kbe/P-11.

Benn, D.I., Evans, D.J.A., 2010. Glaciers and Glaciation. Second edition. Hodder Arnold Publication London.

Bennett, M.R., 2001. The morphology, structural evolution and significance of push moraines. Earth-Science Reviews 53, 197- 236.

Ber, A., Krzywicki, T., Marks, L., Nowacki, Ł., Pochocka-Szwarc, K., Rychel, J., Woronko, B. 2012. Rozwój rzeźby Wzgórz Sokólskich i Wysoczyzny Grodzieńskiej w czasie zlodowacenia odry. Materiały Konferencji „Czynniki różnicowania rzeźby Niżu Polskiego”, Uniejów 13-15.06.2012, 18-19.

Blair, T.C., McPherson, J.G., 1994. Alluvial fans and their natural distinction from rivers based on morphology, hydraulic processes, sedimentary processes, and facies assemblages. Journal Sedimentary Research 64, 450- 489.

Bluemle, J.P., Clayton, L., 1984. Large-scale glacial thrusting and related processes in North Dakota. Boreas 13, 279-299.

Boratyn, J., 2003. Szczegółowa mapa geologiczna Polski 1:50 000, arkusze: Sokółka (264) \& Sokółka E (1079). PIG, Warszawa.

Boratyn, J., 2006. Objaśnienia do Szczegółowej mapy geologicznej Polski 1:50 000, arkusze Sokółka (264) \& Sokółka E (1079), PIG, Warszawa.

Boulton, G.S., 2006. Glaciers and their coupling with hydraulic and sedimentary processes. In: Knight P.G. (ed.) Glacier science and environmental change. Blackwell Publishing, Oxford, $2-33$

Boulton, G.S., 1986. Push moraines and glacier-contact fans in marine and terrestrial environments. Sedimentology 33, 667-698.

Boulton, G.S., Van der Meer, J.J.M., Beer, D.J., Hart, J.K., Ruegg, G.H.J., 1999. The sedimentary and structural evolution of a recent push moraine complex: Holmstrřmbreen, Spitsbergen. Quaternary Science Reviews 18, 339-371.

Boulton, G.S., Dongelmans, P., Punkari, M., Broadgate, M., 2001. Palaeoglaciology of an ice sheet through a glacial cycle: the European ice sheet through the Weichselian Quaternary Science Reviews 20, 591-625.

Clayton, L., Moran, S.R., 1974. A glacial process-form model. In: Coates, D.R. (Ed.), Glacial Geomorphology. Binghamton Publications in Geomorphology, New York, pp. 89-119.

Echelmeyer, K.A., Clarke, T.S., Harrison, W.D., 1991. Surficial glaciology of Jakobshavns variations in velocity — or a lack thereof. Journal of Glaciology 36, 82-88.
Echelmeyer, K.A., Harrison, W.D., 1990. Jakobshavns Isbrć, West Greenland: seasonal Isbrae, West Greenland. Part I. Surfacemorphology. Journal of Glaciology 37, 368-382.

French, H.M., 2007. The Periglacial Environment. Longman, London. pp. 458.

Gałąza, D., Rychel, J., Krysiak, Z., 2009. Struktury glacitektoniczne a dynamika lądolodu zlodowacenia wisły na zachodnim skłonie Garbu Lubawskiego. Prace Państwowego Instytutu Geologicznego. Struktury glacitektoniczne w Polsce 194, $27-34$.

Galon, R., Roszkówna, L., 1961. Extents of the Scandinavian Glaciations and of their recession stages on the Territory of Poland in the light of an analysis of the marginal forms of inland ice. Przegląd Geograficzny 33, 347-361.

Grosswald, M., 1998. Late-Weichseian ice sheets in Arctic and Pacific Siberia. Quaternary International 45/46, 3-18.

Hermanowski, P., Piotrowski, J.A., 2009, Subglacial drainage and its influence on the dynamics of the Weichselian Odra lobe (in Polish). Przegląd Geologiczny 57, 504-512.

Holland, D.M., Thomas, R.T., Young, B., Ribergaard, M.H., Lyberth, B., 2008. Acceleration of Jakobshavn Isbrć triggered by warm subsurface ocean waters. Nature Geoscience 1, 659664.

Houmark-Nielsen, M., 2004. The Pleistocene of Denmark: a review of stratigraphy and glaciation history. In: Ehlers J. \& Gibbard P.L. (Eds) Quaternary Glaciations - Extent and Chronology. Elsevier, 35-46.

Iverson, N.R., Hanson, B., Hooke, R.L., Jansson, P., 1995. Flow mechanism of glaciers on soft beds. Science $267,80-81$.

Jahn, A., 1970. Zagadnienia strefy peryglacjalnej. PWN, Warszawa: pp 202.

Johansson, P., Lunkka, J.P., Sarala, P., 2011. The glaciation of Finland. In Ehlers, J., Gibbard, P.L., Hughes, P.D. (Eds), Quaternary Glaciations - Extent and Chronology - A closer look. Developments in Quaternary Sciences 15, 105-116.

Kondracki, J., 2000. Geografia regionalna Polski. PWN, Warszawa.

Karasiewicz, M.T., 2006. Maximum range and layout of the marginal zone of the Vistulian ice sheet during the Pomeranian Phase in the vicinity of Lake Narie. Quaestiones Geographicae 25A, 27-37.

Kasprzak, L., 2007, Środowiska sedymentacyjne stożków terminoglacjalnych wewnętrznej części lobu Sławy Śląskiej (faza leszczyńska). In: Kasprzak L. (Ed.) Strefy glacimarginalne Wielkopolski, zapis sedymentacyjny i ekspresja morfologiczna. UAM i SGP Poznań, 47-55.

Kasprzak, L., Kozarski, S., 1984. Facies analysis of the ice-marginal sediments (Poznań phase of Vistulian glaciation in middle Wielkopolska). Prace Uniwersytetu im. Adama Mickiewicza (Poznań) Seria Geografia 29, pp. 54 (in Polish, with English summary).

Kovanen, D.J., Slaymaker, O., 2004. Glacial imprints of the Okanogan Lobe, southern margin of the Cordilleran Ice Sheet. Journal of Quaternary Science 19(6), 547-565.

Kozarski, S., 1995. Deglacjacja północno-zachodniej Polski: warunki środowiska i transformacja geosystemu $(\sim 20 \mathrm{ka}-10 \mathrm{ka}$ BP). Dokumentacja Geograficzna 1, pp. 82.

Krzyszkowski, D., Zieliński, T., 2002. The Pleistocene end moraine fans: controls on their sedimentation and location. Sedimentary Geology 149, 73-92.

Krzyszkowski, D., Gizler, H., Jodlowski, J., Dobosz, T., 1999. Glacial deposits and geomorphology in the zone of the maximum extent of the Weichselian ice sheet between Sława Śląska and Święciechowa, western Poland. Quaternary Studies in Poland $16,47-66$.

Laskowski, K., 2000. Szczegółowa mapa geologiczna Polski w 
skali 1:50 000. Arkusz Supraśl (301) wraz z objaśnieniami. PIG Warszawa.

Marks, L., 2002. Last Glacial Maximum in Poland. Quaternary Science Reviews 21, 103-110.

Marks, L., 2005. Pleistocene glacial limits in the territory of Poland. Przegląd Geologiczny 53, 988-993.

Mickelson, D.M., Colgan, P.M., 2004. The southern Laurentide Ice Sheet. In: Gillespie ,A.R., Porter, S.C. \& Atwater, B.F. (Eds), Quaternary Period in the United States. Elsevier: 1-16.

Mojski, E., 1972. Nizina Podlaska. In: Galon R. (Ed.), Geomorfologia Polski 2. PWN, Warszawa, 318-362.

Morawski, W., 2003. Reconstruction of ice- sheet movement from the orientation of linear glacial landforms and glaciotectonic deformations near Kronowo (western Mazury, Poland). Geological Quarterly 47/4, 339-356.

Morawski, W., 2005. Reconstruction of ice- sheet movement from the orientation of glacial morpholineaments (crevasse landforms): na example from northestern Poland. Geological Quarterly 49/4, 403-416.

Morawski, W., 2009a. Neotectonics induced by ice-sheet advances in NE Poland. Geologos 15, 199-217.

Morawski, W., 2009b. Reconstruction of the Vistula ice stream during the Last Glacial Maximum in Poland. Geological Quarterly $53,305-316$.

Mycielska-Dowgiałło, E., 1998. Znaczenie interpretacyjne brył piaszczystych i żwirowych w osadach fluwialnych i fluwioglacjalnych [Interpretation value of sand and gravel blocks in fluvial and fluvio-glacial deposits]. In: Mycielska-Dowgiałło, E. (Ed.), Struktury sedymentacyjne i postsedymentacyjne w osadach czwartorzeędowych i ich wartość interpretacyjna. Faculty of Geography and Regional Studies, University of Warsaw, Warszawa, 115-120.

Narloch, W., Wysota, W., Potrowski, J.A., 2013. Sedimentological record of subglacial conditioins and ice sweet dynamics of the Vistula Ice Stream (north-central Poland) during the Last Glaciation. Sedimantary Geology 293, 30-44.

Nye, J.F., 1973. Water at the bed of a glacier. Symposium on the hydrology of glaciers. International Association of Scientific Hydrology Publication 95, 189-194.

Nye, J.F., 1976. Water flow in glaciers: jökulhlaups, tunnels and veins. Journal of Glaciology, 17(76), 181-204.

Patterson, C.J., 1997. Southern Laurentide ice lobes were created by ice streams: Des Moines lobe in Minnesota, USA. Sedimentary Geology 111, 249-261.

Patterson, C.J., 1998. Laurentide glacial landscapes: The role of ice streams. Geology 26, 643-646.

Piotrowski, J.A., 1997. Subglacial hydrology in north-western Germany during the last glaciation: groundwater flow, tunnel valleys and hydrogeological cycle. Quaternary Science Reviews $16,169-185$.

Piotrowski, J.A., 1994. Tunnel-valley formation in northwest Germany - geology, mechanisms of formation and subglacial bed condition for the Bornhöved tunnel valley. Sedimentary Geology 89, 107-141.

Piotrowski, J.A., 2006. Groundwater under ice sheets and glaciers. In: Knight P.G. (Ed.), Glacier science and environmental change. Blackwell Publishing, Oxford, 50-59.

Piotrowski, J.A., Kraus, A.M., 1997. Response of sediments to ice-sheet loading in northwestern Germany: effective stresses and glacier-bed stability. Journal of Glaciology 43, 495-502.

Piotrowski, J.A., Tulaczyk, S., 1999. Subglacial conditions under the last ice sheet in northwest Germany: ice-bed separation and enhanced basal sliding? Quaternary Science Reviews 18, 737-751.

Pisarska-Jamroży, M., Zieliński, T., 2014. Pleistocene sandur rhythms, cycles and megacycles: Interpretation of depositional scenarios and palaeoenvironmental conditions. Boreas 43,
$330-348$.

Pisarska-Jamroży, M., Zieliński, T., 2012. Specific erosional and depositional processes in a Pleistocene subglacial tunnel in the Wielkopolska region, Poland. Geografiska Annaler; Series A, Physical Geography, 94, 429-443. doi:10.1111/j.1468-0459. 2012.00466.x.

Punkari, M., 1997. Glacial and glaciofuvial deposits in the interlobate areas of the Scandinavian Ice Sheet. Quaternary Science Reviews 16, 741-753.

Roszko, L., 1968. Recesja ostatniego lądolodu z terenu Polski. In: Galon R. (Ed.), Ostatnie zlodowacenie skandynawskie w Polsce, Prace Geograficzne IG PAN 74, 65-96.

Rychel, J., Karasiewicz, M.T., Krześlak, I., Marks, L., Noryśkiewicz, B., Woronko, B., 2014. Paleogeography of the environment in north-eastern Poland recorded in an Eemian sedimentary basin, based on the example of the Jałówka site. Quaternary International 328-329, 60-73.

Rychel, J., Morawski M., 2014. Rekonstrukcja ostatniego nasunięcia lądolodu i jegi recesji na obszarze Wysoczyzny Białostockiej i Wzgórz Sokólskich. In: Pochocka-Szwarc K. (Ed.), Dynamika lądolodów plejstoceńskich na obszarze Sokólszczyzny i Równiny Augustowskiej. XXI Konferencja Stratygrafia plejstocenu Polski. PIG-PIB Warszawa, 87-88.

Stokes, C.R., Clark, D.D., 2001. Palaeo-ice streams. Quaternary Science Reviews 20, 1437-1457.

Szymczuk, P., Woronko, B., Rychel, J., Karasiewicz, M.T., 2014. Strefa marginalna lobu Knyszewicz (Wzgórza Sokólskie, wschodnia Polska), In: Pochocka-Szwarc K. (Ed.), Dynamika lądolodów plejstoceńskich na obszarze Sokólszczyzny i Równiny Augustowskiej. XXI Konferencja Stratygrafia plejstocenu Polski. PIG-PIB Warszawa, 134-141.

Tulaczyk, S., Kamb, W.B., Engelhardt, H.F., 2000. Basal mechanics of Ice Stream B, West Antarctica. 1. Till mechanics. Journal Geophysical Research 105(B9), 463-481.

Van der Wateren, D.F.M., 1995. Processes of glaciotectonism. In: Menzies, J. (Ed.), Modern Glacial Environments: Processes, Dynamics and Sediments. Butterworth-Heineman, London. Glacial Environment 1, 309-335.

Van der Wateren, D.F.M., 2005. Ice-marginal terrestrial land-systems: southern Scandinavian ice sheet margin. In: Evans, D.J.A. (ed.), Glacial Landsystems, Hodder Arnold, 166-203.

Weckwerth, P., 2010. Evolution of the Torun Basin in the Late Weichselian. Landform Analysis 14, 57-84.

Weckwerth, P., Pisarska-Jamroży, M., 2015. Periglacial and fluvial factors controlling the sedimentation of Pleistocene breccia in NW Poland. Geografiska Annaler, Series A: Physical Geography, 97 (2), 415-430.

Woodward, J., Murray, T., Clarke, R.A., Stuart, G.W., 2003. Glacier surge mechanisms inferred from ground-penetrating radar: Kongsvegen, Svalbard. Journal of Glaciology 49, 473480.

Woronko, B., Rychel, J., Karasiewicz, M.T., Ber, A., Krzywicki, T., Marks, L., Pochocka-Szwarc, K., 2013. Heavy and light minerals as a tool for reconstructing depositional environments: an example from the Jałówka site (northern Podlasie region, NE Poland). Geologos 19(1-2), 47-66.

Wysota, W., Molewski, P., 2011. Chronologia i zasięgi nasunięć lądolodu na obszarze lobu Wisły podczas stadiału głównego ostatniego zlodowacenia. Przegląd Geologiczny 59, 214-225.

Zieliński, T., 1993. Sandry Polski północno-wschodniej - osady i warunki sedymentacji. Uniwersytet Śląski, Katowice.

Zieliński, T., 2015. Sedymentologia, osady rzek i jezior. Wydawnictwo Naukowe Uniwersytetu Adama Mickiewicza, pp. 594.

Zwally, H.J., Abdalati, W., Herring, T., Larson, K., Saba, J., Steffen, K., 2002. Surface melt-induced acceleration of Greenland ice-sheet flow. Science 297, 218-222. 